\title{
Alza's patent upheld
}

The US Court of Appeals for the Federal Circuit has upheld the decision of the Vermont District Court that Alza's patent (US 4,588,580) covering transdermal-patch administration of the narcotic painkiller fentanyl is infringed by Mylan Laboratories, not invalid and not unenforceable. On appeal, Mylan argued that the claims were not correctly construed and that the patent was unenforceable due to inequitable conduct.

Prior to the ' 580 patent, transdermal patches used huge excesses of drug with high solubility to maintain the necessary concentration gradient for prolonged delivery. This design was inappropriate for a narcotic due to the large excesses of controlled substance that remained in discarded patches. The inventors of the ' 580 patent discovered that the skin permeability of fentanyl was highly dependent on the chemical form of the drug, and that incorporating the drug in the patch in the form of a base, rather than the more common fentanyl citrate, achieved satisfactory delivery rates. The patch is sold by Janssen as Duragesic.
Did a prior-art patent (US 4,470,962), which claimed the possibility of using a fentanyl citrate patch, render the ' 580 patent invalid? The district court ruled that it was clear from the prosecution history that the claims contained in the ' 580 patent referred to the base form of fentanyl and excluded the citrate form, therefore the ' 962 patent did not anticipate or render obvious the '580 patent. The court also focussed on the construction of the claim term 'skin permeable'. Both the prosecution history and the specification disclaimed fentanyl citrate, because it was unsuitable for transdermal administration and therefore not classed as a 'skin-permeable form' of fentanyl. Finally, the district court found that although during the prosecution history of the patent one statement had the potential to be misleading, there was no evidence of the requisite intent to deceive in order to conclude inequitable conduct.

ALZA Corp. and Janssen Pharmaceutica v Mylan Laboratories: http://www.fedcir.gov/opinions/04-1344.doc

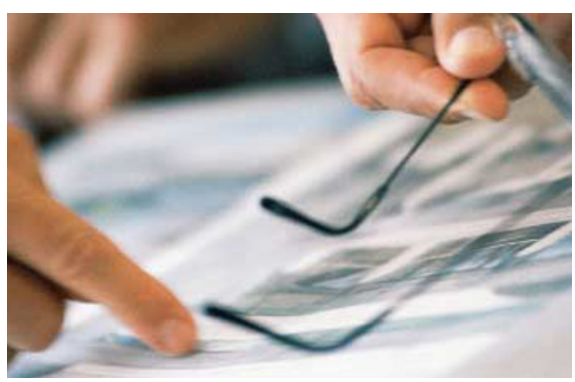

\section{Promoter sequence not novel}

The United States Court of Appeals for the Federal Circuit has upheld a previous decision to deny the patent application US 8,822,509 filed by James F. Crish and Robert L. Eckert, which discloses the isolation and sequencing of the promoter sequence of human involucrin (hINV), a protein that interacts with keratin within epithelial cells.

Claims in the application that refer to a portion of the nucleotide sequence containing the promoter were rejected because they were deemed to be anticipated by two publications authored by Crish. Both papers used plasmids that contained an identical promoter region and one paper disclosed the complete structure of the promoter. However, according to the Apellants, because neither paper specifically disclosed the nucleotide sequence described in the patent application the papers were not prior art.
The board rejects this claim on the basis that the promoter region of hINV was specifically identified by size and location in the previous papers, and that the identification and characterization (that is, sequencing) of a prior-art material does not make it novel. Furthermore, because the plasmids used in both papers necessarily contain the sequence of interest, the Court of Appeals ruled that the pending claims are anticipated by the plasmid in the prior art, and that the Apellants have provided no evidence that the plasmids used in the patent application and the Crish publication were different.

\section{How safe is Safe harbour?}

The US Supreme Court has agreed to review a lower court ruling concerning the breadth of patent protection for research experiments carried out by drug companies that infringe patents. The Drug Price Competition and Patent Term Extension Act, also known as the Hatch-Waxman Act, created a 'safe harbour' exemption that permits drug manufacturers to perform experiments needed to obtain FDA approval of their drugs without incurring liability for patent infringement, even if their activities infringe patent rights.

Biotechnology company Integra alleged that Merck and Scripps infringed patents owned by Integra relating to peptides involved in interactions between cell surfaces and the extracellular matrix. Scripps identified several potential antitumour peptide candidates and selected the most promising peptide by conducting experiments to evaluate the specificity, efficacy and toxicity of the peptide candidates for various diseases. The Appeals Court held that these activities did not fall under the safe harbour because they were exploratory in nature and not done solely for purposes reasonably related to the development and submission of information to the FDA. The court reasoned that the safeharbour provision in the Hatch-Waxman Act was intended only to promote the growth of generic drugs.

However, in a brief submitted to the Supreme Court by the government, it is argued that the current decision of the court of appeals reflects an incorrect view of the law, which is likely to restrict the development of new drugs. The brief holds that creating a distinction between preclinical and clinical research is a misreading of the law, and, in addition, that this is a misunderstanding of the type of information required by the FDA for evaluating potential new drugs.

Merck v Integra Lifesciences, Case number 03-1237

\section{PATENT ADVISORS}

Leslie Meyer-Leon: IP Legal Strategies Group, Cape Cod, MA, USA Philip Webber: Frank B. Dehn \& Co. London, UK George W Schlich: Schlich \& Co, London

Daniel M Becker: Heller Ehrman, Menlo Park, CA, USA 